\title{
AÇÕES AFIRMATIVAS
}

\author{
$\underline{\text { Raquel Sá Mello de Oliveira }}{ }^{1}$; Maria de Lourdes Haywanon Santos Araujo²; \\ 1. Bolsista PIBIC/CNPq, Graduando em Licenciatura em Matemática, Universidade Estadual de Feira de Santana, e-mail: \\ raquelsamello@hotmail.com \\ 2. Orientador, Departamento de Educação, Universidade Estadual de Feira de Santana, e-mail: marialore10@ gmail.com
}

PALAVRAS-CHAVE: ações afirmativas; política de permanência; cotas.

\section{INTRODUÇÃO}

É preciso falar sobre Afirmações Afirmativas, medidas voltadas para grupos discriminados e vitimados pela exclusão social. Considerando o cenário atual brasileiro, apesar da população negra e parda ser a maior do país, em relação à distribuição de renda, temos uma maior concentração das riquezas entre a população branca.. Segundo dados do IBGE, em 2014, o $1 \%$ mais rico do Brasil é formado de $79 \%$ de brancos e $17,4 \%$ negros. A história do povo negro no Brasil tem início em 1500 com a colonização, trazidos pelos europeus, forçados a trabalhar em regime de escravidão e não tinham direito a educação. Antes da criação da primeira universidade brasileira, o acesso às universidades era na Europa, logo só estudava quem tinha condições de ir ao exterior o que era um privilégio exclusivamente da elite branca. A abolição da escravatura ocorreu no ano de 1888, porém não garantiu aos negros melhoria de vida e sim, um trabalho minimamente assalariado, então os filhos de negros (ex escravos) continuavam sem acesso a educação. Mesmo mais de um século após a criação da Lei Áurea e vários movimentos sociais em prol da equidade social, o total de negros na universidade é menor que o de brancos. Dados de pesquisa realizada pelo IBGE em 2013 evidenciam essa diferença. Conforme reportagem publicada no site do jornal G1, "Em 2013, 40,7\% dos negros de 18 a 24 estavam no ensino superior. Já entre o grupo de brancos da mesma idade, 69,4\% estavam matriculados em cursos de graduação no ano passado.". Na introdução do livro "Educação e ações afirmativas: entre a injustiça simbólica e a injustiça econômica", o autor trás vários dados de diferentes fontes de pesquisa acerca do número de negros que vai diminuindo gradativamente enquanto o do branco vai aumentando desde o ensino básico, ao ensino superior. Ainda na introdução, ele diz:

Todos os indicadores apresentados, em especial aqueles relativos ao ensino superior, indicam que a longa caminhada que um aluno faz desde que ingressa na sua primeira série do ensino fundamental até o aceso ao nível superior funciona como um grande filtro racial que privilegia os brancos e bloqueia os negros e pardos. (Pinto, 2003. p. 18)

Um exemplo é o vestibular da Fuvest de 2002, os autodeclarados negros eram apenas $3,1 \%$ dos inscritos e destes $1,4 \%$ obtiveram aprovação. Já os brancos e pardos eram $77,5 \%$ e $11,4 \%$ respectivamente de inscritos, sendo que os aprovados foram $80,5 \%$ brancos e $7 \%$ pardos. No curso de Medicina, considerado de maior concorrência, o número de negros inscritos era $1,6 \%$ e $0,5 \%$ de aprovação e entres os pardos $7,9 \%$ inscritos e índice de aprovação de $4,5 \%$. O sistema de cotas foi implantado nas universidades com o intuito de equalizar o número de brancos e negros, principalmente nos denominados cursos de elite cursos com alta concorrência e de custo alto de manutenção/formação. O presente trabalho tem o intuito de apresentar elementos que subsidiem discussões sobre questão da equidade de raça dentro das universidades baianas e mostrar o quão é importante a implementação de ações afirmativas e de políticas de permanência. É importante ressaltar que as políticas de permanência são de suma importância pelo fato de, as pessoas que tem direito as políticas de 
acesso, geralmente não tem condições suficientes para se manter na universidade ao mesmo tempo que estudam (principalmente os cursos diurnos), logo através das ações de permanência - Restaurante universitário Subsidiado, Residência, Bolsas diversas vinculadas a projetos - as mesmas tem a oportunidade de se manter na Universidade, participando mais efetivamente da vida acadêmica.

\section{MATERIAL E MÉTODOS OU METODOLOGIA (ou equivalente)}

A pesquisa foi investigativa e de organização de dados. Foram organizados em planilhas alguns dados já existentes acerca da pesquisa em planilhas como as resoluções referentes as Universidades Estaduais Baianas (UEBAs), legislações federais, instruções normativas, tabelas referentes a entrada de estudantes nas universidades, reuniões, no intuito de facilitar futuras pesquisas. Foi feita também uma atualização desses dados, até o ano de 2016.

Utilizamos também procedimento de Revisão Sistemática de Literatura, com os seguintes passos:

- Primeiro foram buscados periódicos no portal da Capes que publicam na área de Educação, políticas educacionais, ações afirmativas;

- Definimos palavras chaves para encontrar os textos publicados na temática ações afirmativas em universidades (ações afirmativas, cotas, política de acesso, política de permanência);

- Os resultados foram filtrados para língua portuguesa;

- Depois filtrados para artigos;

- Foram escolhidas as revistas que mais publicam no assunto nos últimos dez anos (de acordo com a busca no portal de periódicos) e catalogados.

\section{RESULTADOS E/OU DISCUSSÃO (ou Análise e discussão dos resultados)}

Foram levantados todos os registros públicos existentes acerca do que tem ocorrido no âmbito das Universidades baianas em relação às políticas de acesso e de permanência. Para ratificar a importância das políticas de ações afirmativas, temos um estudo feito na Universidade Estadual da Bahia em 2003 sobre o sistema de cotas:

Pode-se afirmar que o sistema de cotas garante o acesso grupal mínimo dos afrodescendentes ao ensino superior e esta é a principal característica a confirmar a sua necessidade e legitimidade social. Mas, se de imediato ela consegue, no acesso, transpor (parcialmente, porque limitado ao quantum da cota) a barreira da desvantagem relativa, por si só, ao menos no curto prazo, ele não consegue anular os fatores estruturais que determinam o conteúdo dessa desvantagem, qual seja, a desigualdade racial básica, socialmente determinada. (Mattos, 2003. p. 143)

Também é de extrema importância esclarecer a comunidade, não só acadêmica, o real sentido das políticas de ações afirmativas.

O volume de dados da pesquisa é grande, o que demandará um tempo maior para análise dos mesmos. Em contrapartida, não há um volume de publicações sobre pesquisas na área o que implica em tempo maior para estabelecer trajetória de pesquisa na temática. Ainda falta muito a ser organizado, analisado, discutido e melhorado. Seguindo a linha de raciocínio de Mattos, as cotas melhoraram o quadro em relação ao número de negros dentro do ensino 
superior, porém essas políticas por si só não darão conta de promover a total equidade dentro das universidades, se fazendo necessários mais estudos acerca do tema.

\section{CONSIDERAÇÕES FINAIS (ou Conclusão)}

Esse recorte da pesquisa permitiu a atualização e organização dos documentos, publicações e materiais sobre políticas de permanência das Universidades Estaduais Baianas. Hoje o projeto tem de forma organizada e atualizada, separados por categorias os documentos que são públicos dessas Universidades, além de um estado da arte sobre o tema no Brasil. O trabalho desenvolvido servirá de subsídio para as análises e discussões posteriores na continuidade dessa pesquisa e de outras que poderão utilizar o banco de dados organizado. São necessárias mais pesquisas acerca do assunto, a fim de facilitar o debate e aprofundar cada vez mais as mesmas. Outra questão é o sigilo com o qual se tratam os dados nessa temática nas universidades. Parcerias entre pesquisadores dessa área seriam de suma importância para a facilitação de troca de informações, documentos, dados e tudo que ajudasse na conclusão de uma pesquisa que tem uma importância tão atual e necessária.

\section{REFERÊNCIAS}

G1, $\mathrm{N}^{\mathrm{o}}$ de negros na faculdade em 2013 é menor que o de brancos em 2004. Disponível em: $<$ http://g1.globo.com/educacao/noticia/2014/12/n-de-negros-na-faculdade-em-2013-emenor-que-o-de-brancos-em-2004.html>. Acesso em 23 de setembro de 2016.

MATTOS, Wilson Roberto. Ação Afirmativa na Universidade do Estado da Bahia: razões e desafios de uma experiência pioneira. In. SILVA, Petronilha Beatriz Gonçalves. Educação e Ações Afirmativas: Entre a injustiça Simbólica e a injustiça Econômica. Brasília: INEP, 2003. O Paraná, Negros representam 54\% da população do país, segundo o IBGE. Disponível em:< http://www.oparana.com.br/noticia/negros-representam-54-da-populacao-do-pais-segundo-oibge/3908/>. Acesso em 19 de setembro de 2016.

SILVA, Petronilha Beatriz Gonçalves. Educação e Ações Afirmativas: Entre a injustiça Simbólica e a injustiça Econômica. Brasília: INEP, 2003 